\title{
A Microbiological Study of Sediments from the Cumbrian Lakes
}

\author{
By J. GWYNFRYN JONES, MIRNA J. L. G. ORLANDI \\ AND BERNARD M. SIMON \\ Freshwater Biological Association, The Ferry House, \\ Ambleside, Cumbria LA22 OLP
}

(Received 10 May 1979)

\begin{abstract}
The microbiology of the benthos of 16 lakes in Cumbria was studied. The lakes formed a series ranging from oligotrophic to eutrophic, and the results were compared with other surveys of their chemistry and biology. The sediments of the more productive lakes contained more organic matter, $E_{\mathrm{h}}$ measurements indicated that they were more reduced, and the overlying water was deoxygenated to a greater degree. These results correlated with greater microbial activity, biomass and numbers in the sediments of the richer lakes, as measured by electron transport system activity, ATP and direct counts. The data obtained from the sediments were, however, more variable, and showed poorer agreement with the assumed ranking of the lakes than the results obtained from the water column in this and past surveys. The microbiology of the benthos suggested that the more productive lakes might be considered as a distinct group, but more detailed sampling and careful choice of indicator micro-organisms would be required to provide statistically significant evidence for this.
\end{abstract}

\section{INTRODUCTION}

Interest in lake classification has led to a number of comparative studies of lakes of differing trophic status. This status is related to the size and shape of the lake (morphometric eutrophication) and its nutrient input (cultural eutrophication) (Odum, 1971). Although nutrient enrichment has received particular attention in recent years both components may be of importance particularly in relation to deoxygenation of the hypolimnion and metabolism in the profundal zone. Lakes in other parts of the world have been classified on the basis of catchment area:volume ratio (Schindler, 1971), hypolimnetic oxygen concentration and benthic fauna (Kitagawa, 1978) and oxygen deficits and clarity (Stewart, 1976). Indices of lake trophic state derived from multivariate analysis have been used successfully (Shannon \& Brezonik, 1972) to determine fertilized cropland and urban areas as major influences on Florida lakes. However, maturity indices, based on primary productivity and other variables associated with the euphotic zone, were apparently less useful in Colorado (Winner, 1972), possibly due to inadequate characterization. Measurements of microbial biomass and activity (chlorophyll $a$ concentration, direct counts of bacteria, ATP concentration, and heterotrophic potential - the $V_{\max }$ for single substrate metabolism) have been used to rank New Zealand lakes (Gillespie, 1976; Spencer, 1978).

Pearsall (1921) considered the lakes of the English Lake District as a series, illustrating the stages in post-glacial development, although within this series classes were also recognized, characterized by the degree of cultivation of the drainage basin and the degree of silting within the lakes. Since Pearsall's original paper, several studies have been published which are relevant to a microbiological investigation of the series. Not every paper is concerned with all the major lakes in this area, but valuable comparative information on 
the series may be obtained from them. Details of the morphometry and drainage basin area of the 15 major lakes are summarized by Ramsbottom (1976). Phytoplankton and benthic algae were investigated by Pearsall (1932), Lund (1957) and Round (1957). The relationship between algal standing crops and productivities, and sediment and water chemistry were reported by Round (1957) and Gorham et al. (1974), the latter authors drawing together much of the earlier work on the lakes series. The underwater light climate, and depth of penetration of light of different wavelengths, has been considered as another factor controlling the production of phytoplankton in 16 of the lakes (Talling, 1971). Mackereth (1957) discussed the chemical differences between the Lake District tarns and lakes and Mortimer (1942), the physico-chemical properties, particularly $E_{\mathrm{h}}$, governing nutrient exchange between the sediment and the water column. Decomposition processes in the hypolimnion are driven to a considerable degree by the input of sedimenting material. Gorham et al. (1974) studied sediment between approximately 5 and $20 \mathrm{~cm}$ depth and concluded that much of the organic matter in the sediments of productive lakes was autochthonous in origin. Mackereth (1966) accounted for longer term changes in the chemistry of post-glacial sediments (the depth range for these lakes is 4 to $6 \mathrm{~m}$ ) in terms of erosion rate from the drainage basin (i.e. allochthonous input). This apparent inconsistency may reflect, in part, differences in sampling method and depth but can also be resolved by considerations of catchment land use, particularly deforestation (Pennington, 1978). A more detailed discussion on sedimentation in five of the lakes is provided by Pennington (1974). In a study of the planktonic community, Jones (1972) compared algal biomass, bacterial plate counts and microbial phosphorus mineralization (phosphatase activity) with phosphorus chemistry and dissolved oxygen concentrations. Although there were minor differences in the ranking of the lakes in the above papers, these were confined to those in the middle order, and agreement was generally good at the oligotrophic and eutrophic extremes.

This paper examines the relationship between lake trophic status and microbial numbers, biomass and activity, with particular reference to the benthic communities. Analysis of the planktonic communities had shown that the lakes fell into a true series with a steady transition from oligotrophic to eutrophic. This study was intended to examine whether this was reflected in the benthos and whether general microbiological variables might be used as indicators of the degree of enrichment.

\section{METHODS}

Sampling sites and programme. Samples were taken over the deepest point of each lake, the positions and depths of which are given in Ramsbottom (1976). Random samples were taken during 1977, but three sampling trips were made to each lake during 1978. These ran from 26 April to 11 May, from 17 July to 28 July and from 24 August to 8 September. The dates were chosen so that comparable estimates of hypolimnetic oxygen depletion could be made.

Sampling methods. Water samples were taken with a $5 \mathrm{~m}$ tube in the epilimnion (Lund et al., 1958) and $1 \mathrm{~m}$ above the sediment with a Friedinger water bottle. Sub-samples were taken into sterile glass bottles for microbiological analysis and acid-washed polythene bottles for chemical determinations. Sediment samples were taken with a Jenkin surface mud corer and retained in their cores until returned to the laboratory. The sediment was then extruded using the device described by Jones (1976) during which $E_{\mathrm{h}}$ readings were taken. Sediment to a depth of $1 \mathrm{~cm}$ was then removed for analysis. Dissolved oxygen and temperature were measured in the field with a combination thermistor/oxygen electrode (Mackereth, 1964).

$E_{\mathrm{h}}$ measurements. The sediment $E_{\mathrm{h}}$ (cell potential plus the potential of the reference electrode) was measured with a bright platinum electrode and a calomel reference electrode as described by Jones (1979).

Sediment carbon and nitrogen analysis. Samples were dried to constant weight at $80^{\circ} \mathrm{C}$ and their $\mathrm{C}$ and $\mathrm{N}$ content was determined on a Hewlett-Packard F \& M 185 CHN analyser.

Chlorophyll $a$. The sediment chlorophyll $a$ concentration was determined by extracting $2 \mathrm{ml}$ of sediment in $18 \mathrm{ml}$ of A.R. grade cold acetone, except for the more productive lakes, when $0.5 \mathrm{ml}$ was extracted and the volume made up with distilled water. The extract was mixed thoroughly and then stored overnight at $4{ }^{\circ} \mathrm{C}$. The contents of the tube were then agitated vigorously and the extract was cleared by centrifugation. 
The absorbance of the extract was determined at 665 and $750 \mathrm{~nm}$ before and $1 \mathrm{~min}$ after acidification with 0.1 vol. $\mathrm{HCl}$.

Chloroplast counts. The number of viable algal cells in the sediment was estimated by counting chloroplasts under an epifluorescence microscope. A $10^{-3}$ dilution of the sediment in tap water was homogenized for $1 \mathrm{~min}$ in an Ultra-Turrax homogenizer (Sartorius Instruments, Belmont, Surrey). A sample $(5 \mathrm{ml})$ of the homogenate was then filtered through a $0.45 \mu \mathrm{m}$ pore-size black membrane filter and counted under an epifluorescence microscope, using a Calflex B1/K2 interference heat filter and two BG12 filters (total thickness $4.5 \mathrm{~mm}$ ) for an excitation spectrum which ranged from 320 to $490 \mathrm{~nm}$ with a maximum at $400 \mathrm{~nm}$.

Bacteria, direct counts. Planktonic and benthic bacteria were counted directly using epifluorescence microscopy and the procedure of Jones \& Simon (1975). Benthic samples were diluted $10^{-3}$ with membrane-filtered water and homogenized as described for chloroplast counts to disperse clumps before staining with acridine orange at a final concentration of $10 \mathrm{mg} \mathrm{l}^{-1}$.

Bacteria, viable counts. The Harris \& Sommers (1968) most probable number (MPN) procedure was used to enumerate aerobic bacteria on casein/peptone/starch (CPS) medium (Collins \& Willoughby, 1962) and anaerobic bacteria on CPS medium plus $0 \cdot 1 \mathrm{~g} \mathrm{l}^{-1}$ each of $\mathrm{NaNO}_{3}, \mathrm{Na}_{2} \mathrm{SO}_{4} \cdot 10 \mathrm{H}_{2} \mathrm{O}$ and $\mathrm{Na}_{2} \mathrm{CO}_{3}$. . The replidishes used were incubated aerobically at $15^{\circ} \mathrm{C}$ for $14 \mathrm{~d}$, and anaerobically at $20^{\circ} \mathrm{C}$ for $10 \mathrm{~d}$ using the GasPak anaerobic system (BBL).

$A T P$. The ATP content of water and sediment was determined using a sensitive modification of the conventional firefly luciferase method as described by Jones \& Simon (1977). Sediment was diluted $10^{-3}$ immediately before extraction in actively boiling Tris buffer at $\mathrm{pH} 7 \cdot 8$. Internal standards (bacterial cultures) were analysed with each sediment sample.

Electron transport system (ETS) activity. This was used as a measure of microbial energy-yielding metabolism in the sediments. The method used was that of Owens \& King (1975) as modified by Jones \& Simon (1979) to ensure optimum conditions for extraction of enzymes from freshwater sediments.

Data analysis. Areal oxygen deficits in the hypolimnia of the lakes were calculated using the procedures described by Jones (1976) and the bathymetric data in Ramsbottom (1976). Where necessary, non-parametric statistical tests were used for data analysis (Jones, 1973) because the parent distribution of many of the variables was not known, and also because most of the comparisons were for the purpose of ranking the results from the lakes.

\section{RESULTS AND DISCUSSION}

Some features of the 16 lakes studied are summarized in Table 1 . The lakes are ranked in order of increasing degree of enrichment according to Jones (1972). Further tables of background information have been provided by Gorham et al. (1974), Jones (1972), Pennington (1978) and Ramsbottom (1976) and therefore only the information of greatest relevance to a microbiological survey is presented. The human population estimates were taken from a more recent census than that used by Macan (1970), but some difficulty was experienced in estimating the population distribution on the basis of lake catchments. This was particularly true of Esthwaite Water and Blelham Tarn and those areas where a large tourist influx occurred. Some estimate of the latter could be obtained from sewage discharge volumes. These were subject to several errors, particularly the absence of calculated inputs from camp sites and establishments not connected to piped sewerage schemes, and clearly underestimated the population in the Esthwaite Water drainage basin. All measures of microbial population density, biomass and activity increased with the degree of eutrophication of the water body. Most of the data in Table 1 were obtained from the epilimnion and therefore this survey concentrated on the profundal zone, particularly the benthos.

The $E_{\mathrm{h}}$ profile of each sediment core was determined, and the results are summarized in Fig. 1. There has been no consensus on how such results should be presented, short of providing details of each profile or, if sufficient data are available, a seasonal depth-time diagram for each lake. The degree of reduction of a sediment will depend on the carbon and energy input and oxygen consumption as well as the reducing power of the sediment itself. Figure 1 attempts to illustrate this in three ways. The mean depth of the $E_{\mathrm{h}}$ gradient, and the depths of the $0 \mathrm{mV}$ and $+200 \mathrm{mV}$ readings were calculated. Mortimer (1942) considered that the +0.2 isovolt represented the boundary between oxidizing and reducing conditions. Hutchinson (1957) extended this to suggest that the presence of an oxidized 


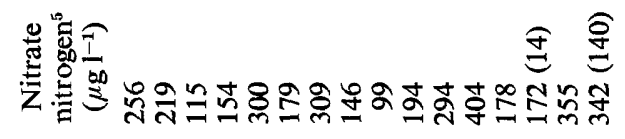
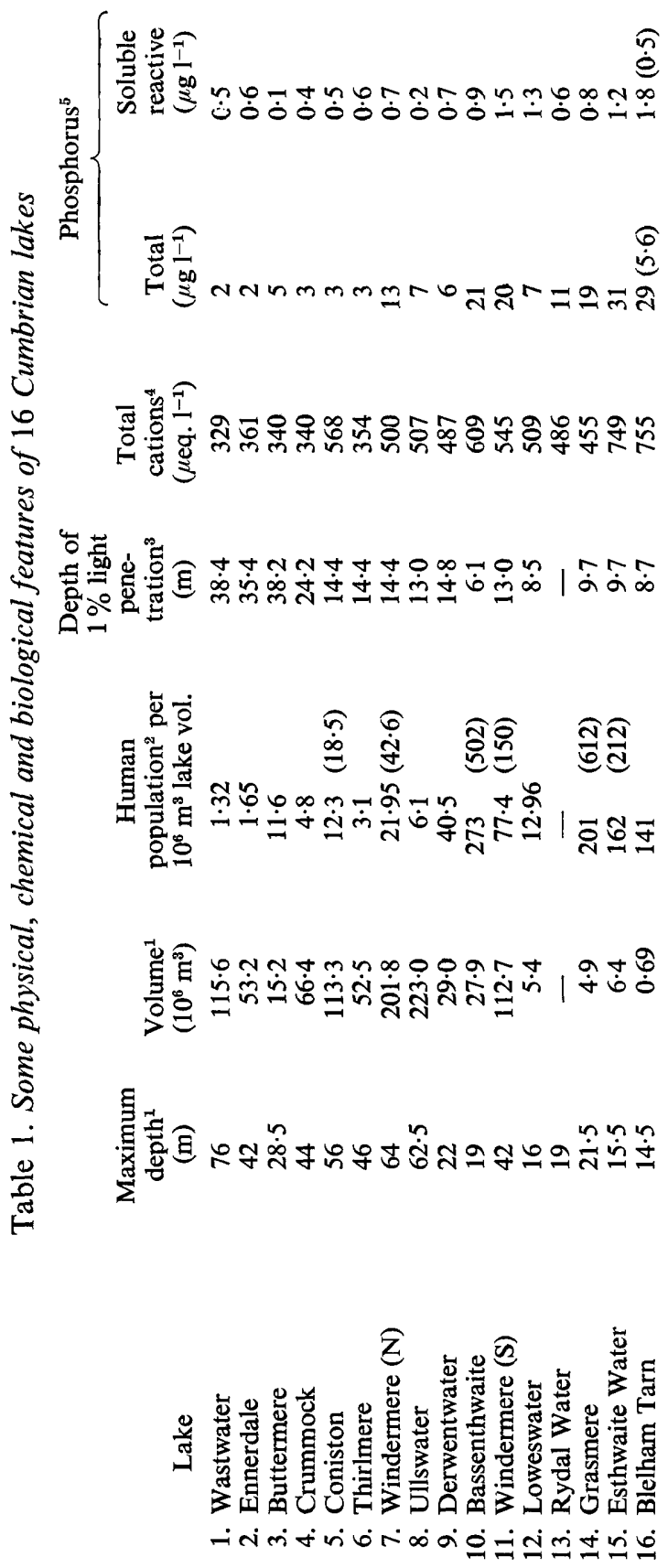


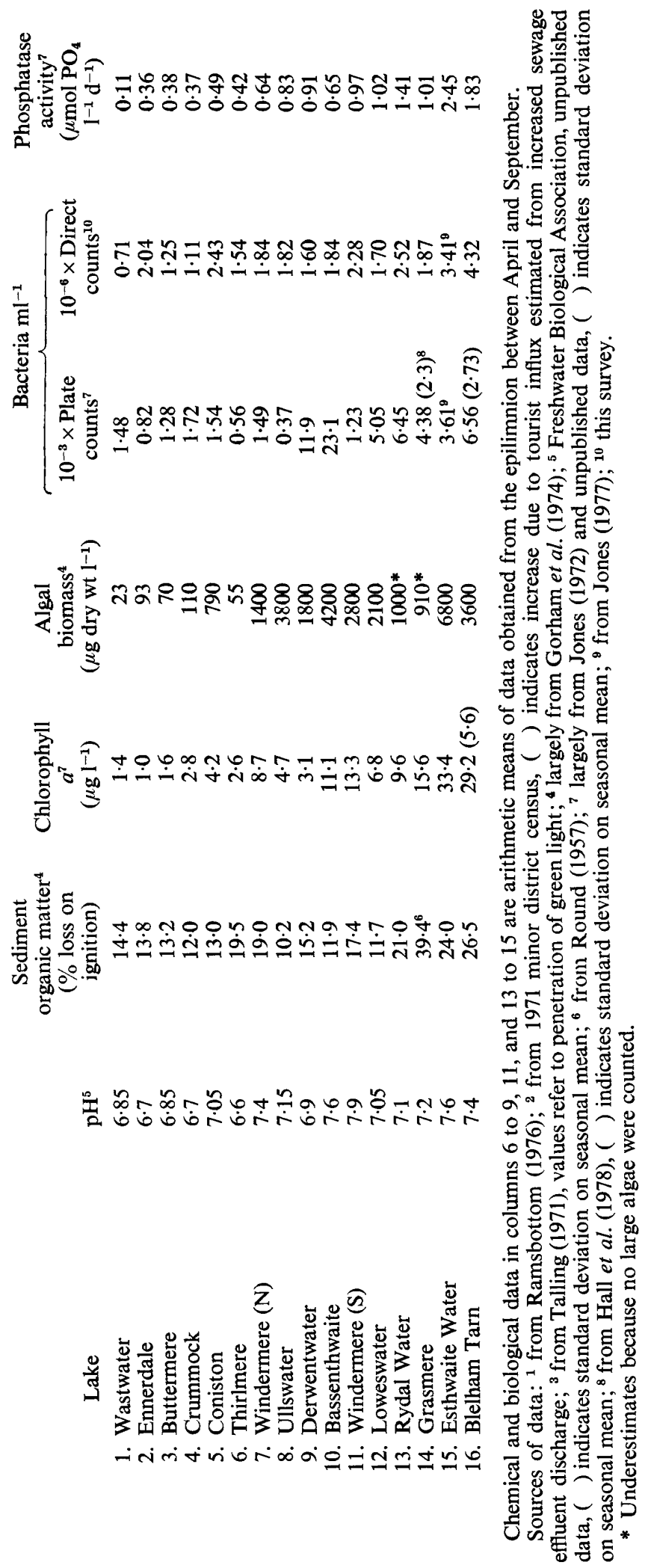




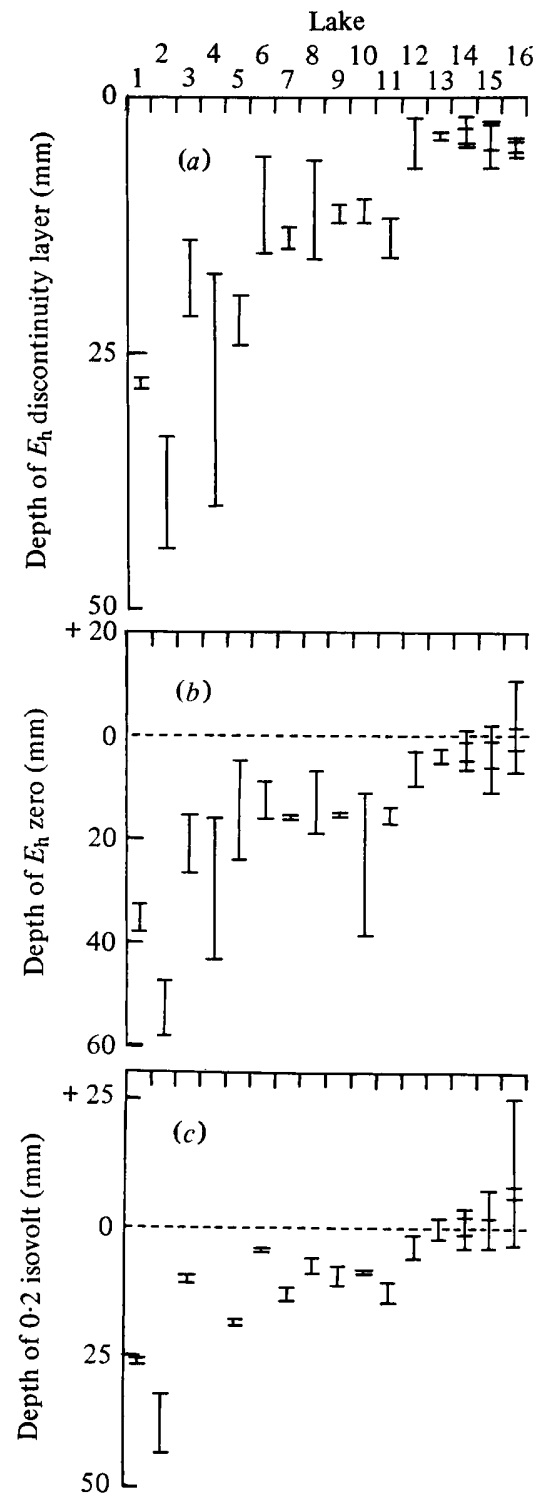

Fig. 1

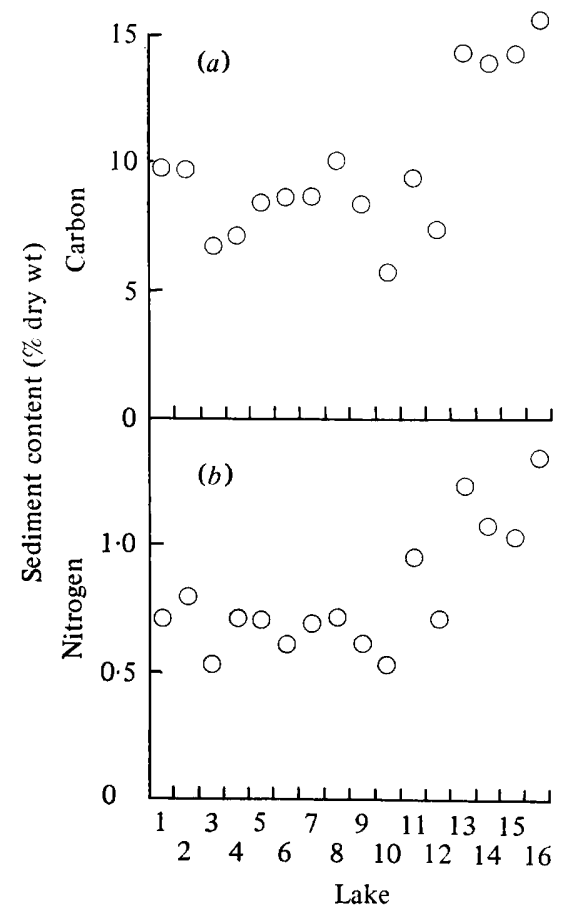

Fig. 2

Fig. 1. Analysis of $E_{\mathrm{h}}$ profiles in the sediments from the lakes described in Table 1 (lake numbering as in the Table). The ranges of readings obtained during the period of thermal stratification are shown (thermal stratification is defined, for this and subsequent figures, as the period between the onset of a $1{ }^{\circ} \mathrm{C}$ temperature difference between surface water and bottom water, and the autumn overturn when isothermal conditions are re-established). The result of each profile is represented by a horizontal bar. (a) Depth of the $E_{\mathrm{h}}$ discontinuity layer $(b)$ Depth of $E_{\mathrm{h}}$ zero. $(c)$ Depth of the $0 \cdot 2$ isovolt.

Fig. 2. Carbon (a) and nitrogen (b) content of surface sediment from the lakes described in Table 1; samples were taken during thermal stratification in 1977.

microzone throughout the year (i.e. no migration of the $+200 \mathrm{mV}$ level into the overlying water occurred during summer) represented an important dichotomy in the chemical classification of lakes. All three representations of the data obtained on this survey illustrated the more reducing nature of the sediments from the more eutrophic lakes. The $+200 \mathrm{mV}$ value 


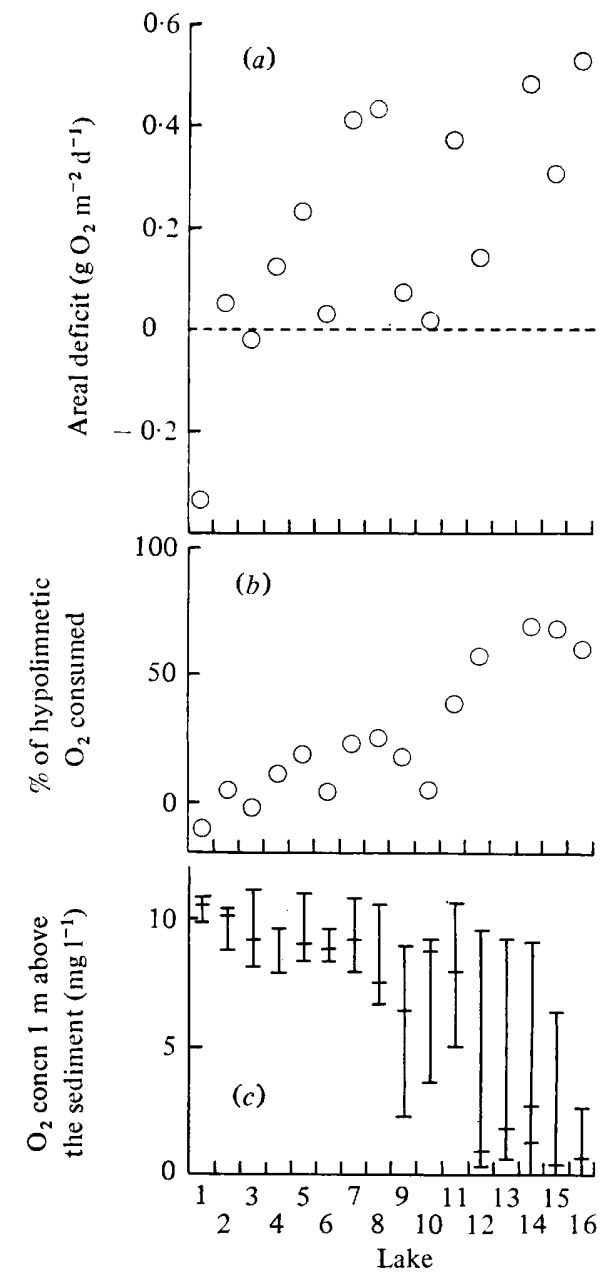

Fig. 3

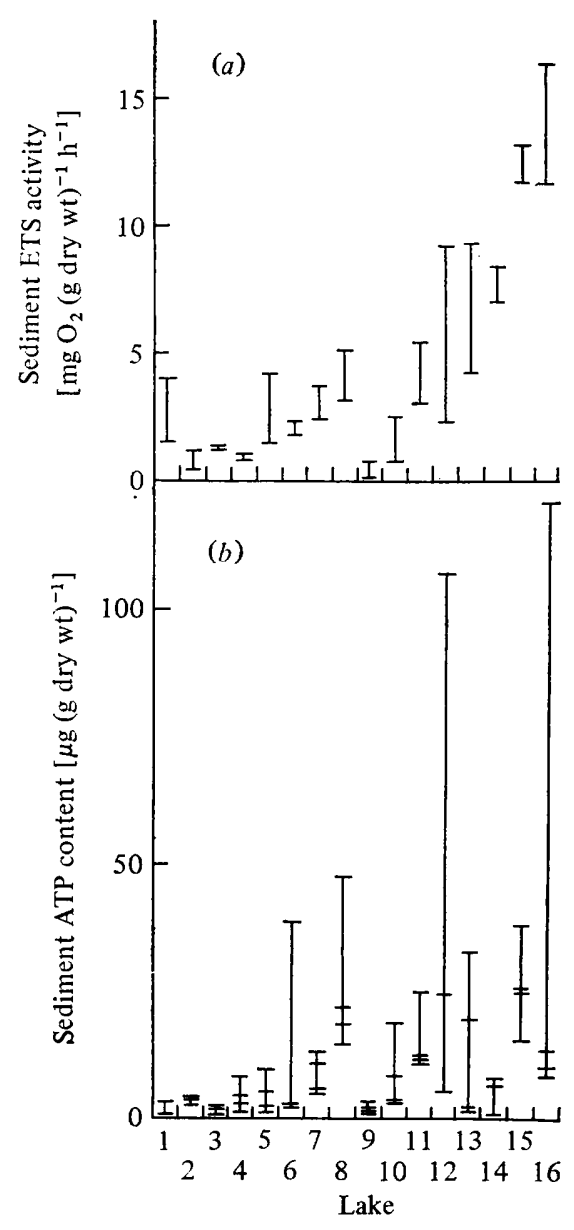

Fig. 4

Fig. 3. Hypolimnetic oxygen consumption in the lakes described in Table 1 between April and September 1978. (a) Calculated areal deficit. (b) Oxygen consumed, expressed as a percentage of the total oxygen content of the hypolimnion in April. (c) Range of oxygen concentrations observed $1 \mathrm{~m}$ above the sediment during the period of thermal stratification; each reading is represented by a horizontal bar.

Fig. 4. Electron transport system activity $(a)$ and ATP content $(b)$ of surface sediments from the lakes described in Table 1; each measurement is represented by a horizontal bar.

migrated into the overlying water in Rydal Water, Grasmere, Esthwaite Water and Blelham Tarn. These results correlated well with the carbon and nitrogen content of the sediments (Fig. 2) and the oxygen content of the overlying water (Fig. 3). The sediments of the eutrophic lakes contained more organic matter and the values obtained were in good agreement with those of Gorham et al. (1974), Pennington (1978) and Round (1957). Hypolimnetic oxygen consumption was expressed in terms of the areal deficit (Fig. $3 a$ ), the percentage of hypolimnetic oxygen consumed (Fig. $3 b$ ) and the range of oxygen concentrations observed $1 \mathrm{~m}$ above the sediment during the period of thermal stratification (Fig. $3 c$ ). All showed a trend of increased oxygen consumption with degree of enrichment, and the oxygen concentrations were similar to those reported by Jones (1972), with the possible exception of Grasmere, where increased oxygen consumption has been observed since the introduction 


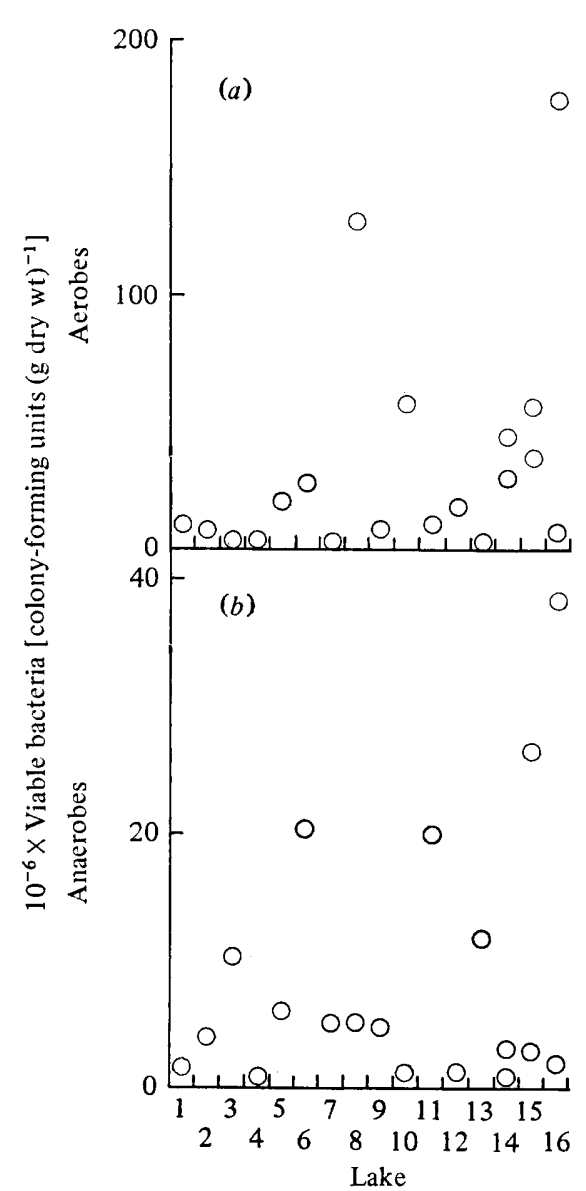

Fig. 5

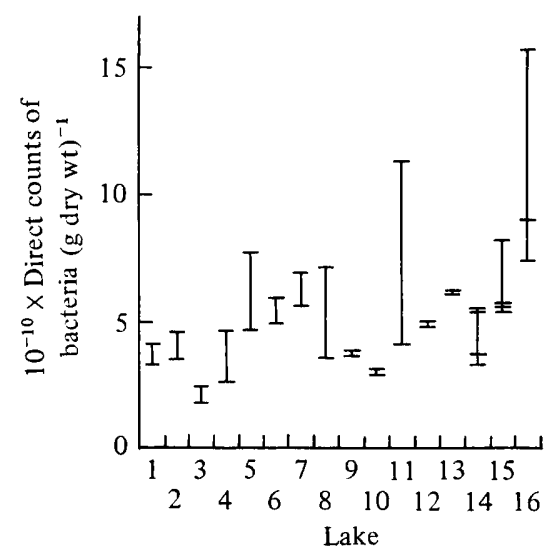

Fig. 6

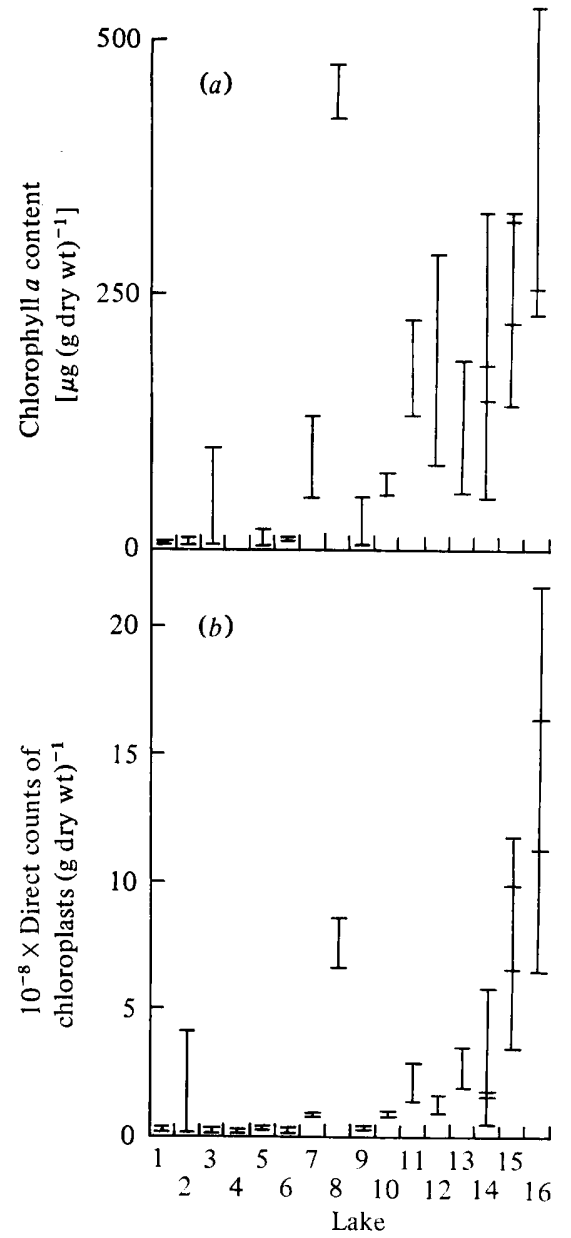

Fig. 7

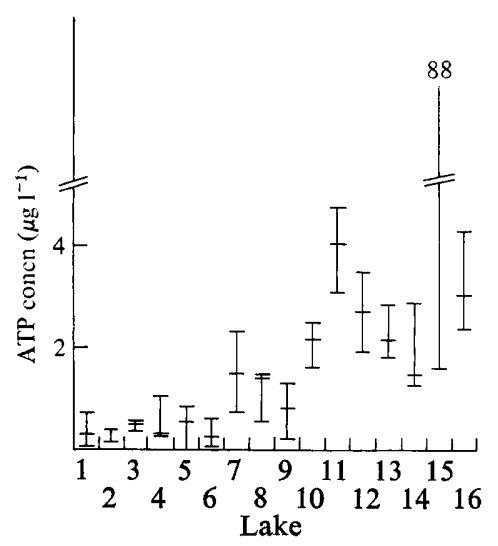

Fig. 8

Figs 5-8. For legends see facing page. 
of sewage effluent to the lake in 1971 (Hall et al., 1978). The areal deficits were somewhat variable, possibly reflecting the long time scale used, which might also account for the relatively low values obtained for the more eutrophic lakes (cf. Mortimer, 1942; Jones, 1976). Hutchinson (1957) related the rate of hypolimnetic oxygen loss to the type of lake and suggested 40 to $330 \mathrm{mg} \mathrm{O}_{2} \mathrm{~m}^{-2} \mathrm{~d}^{-1}$ for oligotrophic and 500 to $1400 \mathrm{mg} \mathrm{O}_{2} \mathrm{~m}^{-2} \mathrm{~d}^{-1}$ for eutrophic lakes, but also commented that Mortimer's values of $<250$ and $>550 \mathrm{mg} \mathrm{m}^{-2} \mathrm{~d}^{-1}$ as the boundaries for oligotrophic and eutrophic waters might be more convenient. Although hypolimnetic areal oxygen deficits have been used successfully in comparative studies and in the estimation of decomposition processes (Edmondson, 1966; Jones, 1976), some doubts have been expressed concerning their general applicability (Stewart, 1976; Hall et al., 1978). The values for the percentage of the hypolimnion volume deoxygenated (Fig. $3 b$ ), particularly if combined with a time factor, may provide a more useful guide to events in the lake.

The increased respiratory activity in the richer lakes suggested by the above results was confirmed by an examination of their microbiological characteristics. Energy metabolism, as measured by electron transport system (ETS) activity, was highest in Blelham Tarn and Esthwaite Water (Fig. 4a) and although an upward trend in ATP content was also observed (Fig. $4 b$ ) with increasing degree of enrichment, the range of values was much wider. This upward trend was also observed in viable counts of aerobic and anaerobic bacteria (Fig. 5), direct counts of bacteria (Fig. 6), chlorophyll $a$ concentration (Fig. 7a) and direct counts of chloroplasts in the sediment (Fig. $7 b$ ). The viable counts did not agree particularly well with the ranking of the lakes, and the scatter of points with the viable counts and the range of the direct counts was greater than that observed for the plankton (Jones, 1972, and Table 1). The chlorophyll $a$ estimates and chloroplast counts of this survey, and published estimates of benthic algal standing crops (Round, 1957), were not strictly comparable since the latter were made on samples taken from littoral sites. Analysis of the ATP content of the plankton (Fig. 8) showed that the general trends in microbial biomass observed by Jones (1972) still occurred.

The variables measured on this survey showed a high degree of inter-correlation as tested by calculating Kendall's rank correlation coefficient. The results from the benthos were, however, more variable, and showed poorer agreement with the assumed ranking of the lakes than had been obtained on analysis of data from the water column (Table 2). Data obtained from the plankton in this and previous surveys showed significant correlations $(P=0.05)$ between variables, and between the variates and assumed lake rank, in over $85 \%$ of cases. This was true of only $60 \%$ of the cases when results from the benthos were analysed. There was good agreement between results from lakes at either end of the scale, particularly from the more productive waters, and indeed the lakes might be conveniently placed in three groups, representing mean ranks of 0 to 5,5 to 10 and 10 to 16 .

The results from Bassenthwaite suggested that it might be incorrectly placed in the series, but whereas the plankton analysis suggested that it might be more eutrophic, the results from the benthos suggested the opposite. This may reflect the instability of thermal stratifi-

Fig. 5. Viable counts of aerobic $(a)$ and anaerokic $(b)$ bacteria from surface sediments of the lakes described in Table 1. Samples were taken during thermal stratification in 1977.

Fig. 6. Direct counts of bacteria in surface sediments of the lakes described in Table 1. Samples were taken in 1977 and 1978 during thermal stratification; each sample count is represented by a horizontal bar.

Fig. 7. Chlorophyll $a$ content $(a)$ and direct ccunts of chloroplasts $(b)$ in surface sediments of the lakes described in Table 1. Samples were taken in 1977 during thermal stratification; each measurement is represented by a horizontal bar.

Fig. 8. ATP concentration in the surface water (to a depth ef $5 \mathrm{~m}$ ) of the lakes described in Table 1. Samples were taken in 1977 and 1978 during the period of thermal stratification; each analysis is represented by a horizontal bar. 
Table 2. Assessment of the ranking of Cumbrian lakes based on arithmetic mean values of planktonic and benthic variables*

\begin{tabular}{|c|c|c|c|c|c|c|c|}
\hline \multirow[b]{2}{*}{ Lake } & \multirow[b]{2}{*}{$\begin{array}{c}\text { Assumed } \\
\text { rank }\end{array}$} & \multicolumn{3}{|c|}{ Plankton } & \multicolumn{3}{|c|}{ Benthos } \\
\hline & & $\begin{array}{l}\text { Mean } \\
\text { rank }\end{array}$ & $\begin{array}{c}\text { Rank } \\
\text { CV† (\%) }\end{array}$ & $\begin{array}{c}\text { Rank } \\
\text { displace- } \\
\text { ment }\end{array}$ & $\begin{array}{l}\text { Mean } \\
\text { rank }\end{array}$ & $\underset{\text { CVt }}{\text { Rank }(\%)}$ & $\begin{array}{c}\text { Rank } \\
\text { displace- } \\
\text { ment }\end{array}$ \\
\hline Wastwater & 1 & $3 \cdot 1$ & 92 & 0 & $4 \cdot 2$ & 72 & +2 \\
\hline Ennerdale & 2 & $4 \cdot 0$ & 85 & +2 & $5 \cdot 7$ & 60 & +4 \\
\hline Buttermere & 3 & $3 \cdot 4$ & 47 & -1 & $3 \cdot 5$ & 87 & -2 \\
\hline Crummock & 4 & 3.9 & 54 & -1 & $3 \cdot 8$ & 59 & -2 \\
\hline Coniston & 5 & $7 \cdot 6$ & 48 & +3 & $7 \cdot 6$ & 32 & $+\overline{4}$ \\
\hline Thirlmere & 6 & $4 \cdot 0$ & 47 & -2 & $7 \cdot 6$ & 61 & +2 \\
\hline Windermere (N) & 7 & $9 \cdot 2$ & 24 & $+\overline{2}$ & $7 \cdot 5$ & 37 & 0 \\
\hline Ullswater & 8 & $6 \cdot \overline{8}$ & 48 & -2 & $11 \cdot 7$ & 22 & +6 \\
\hline Derwentwater & 9 & $7 \cdot 2$ & 49 & -2 & 4.9 & 42 & -5 \\
\hline Bassenthwaite & 10 & 11.9 & 25 & +4 & $5 \cdot 2$ & 78 & -5 \\
\hline Windermere (S) & 11 & $11 \cdot 8$ & 27 & +2 & $10 \cdot 8$ & 21 & 0 \\
\hline Loweswater & 12 & $11 \cdot 2$ & 29 & 0 & $9 \cdot 4$ & 38 & -2 \\
\hline Rydal Water & 13 & $10 \cdot 2$ & 31 & -3 & $11 \cdot 1$ & 36 & $-\overline{1}$ \\
\hline Grasmere & 14 & $10 \cdot 4$ & 25 & -3 & $11 \cdot 4$ & 34 & -1 \\
\hline Esthwaite Water & 15 & $14 \cdot 3$ & 15 & 0 & $13 \cdot 7$ & 7 & 0 \\
\hline Blelham Tarn & 16 & $14 \cdot 6$ & 9 & 0 & $15 \cdot 4$ & 7 & 0 \\
\hline
\end{tabular}

* Based on eleven variables each for the plankton and the benthos, obtained from the results of this study, Table 1 and Jones (1972). For the purposes of this comparison, hypolimnetic oxygen depletion was considered as a benthic variable.

$\dagger \mathrm{CV}$, Coefficient of variation, expressed as a percentage of the mean.

cation in Bassenthwaite due to its shallow mean depth and exposure to winds. Benthic analyses indicated that Ullswater might be placed closer to the eutrophic end of the scale (the low coefficient of variation supported this). This would be in agreement with the findings of Pearsall (1921) and Gorham et al. (1974) but not with the general conclusions of the plankton analysis. The position of each lake in the series, and whether the lakes form a continuous series or fall into distinct groups could be discussed at length. The microbiological analyses of the plankton suggested the former whereas the results from the benthos indicated that the more eutrophic lakes might form a distinct group, comprising Rydal Water, Grasmere, Esthwaite Water and Blelham Tarn. This was the largest number of the more productive lakes which could be considered as a group which was significantly different $(P=0.05)$ from the remainder, on the basis of at least four of the variables measured. Such a distinction would correlate with the proposed autochthonous source of sediment organic matter in the more productive waters (Gorham et al., 1974; Pennington, 1978). Multivariate analysis of the microbiological and other variables or construction of indices of eutrophication were not attempted because of insufficient data, which usually did not conform to the underlying assumptions of such analyses. Microbiological analyses of the benthos (Jones, 1976) and the plankton (Heaney, 1976; George \& Heaney, 1978; Jones, 1977) have demonstrated the scale of spatial variability in individual lakes, and increasing seasonal variability with the degree of enrichment has also been observed (Jones, 1971). Clearly, if microbial indicators of eutrophication are to be used, effort would be more profitably spent in obtaining more reliable estimates of a few well chosen variables from larger numbers of samples than attempting sophisticated analyses on inadequate data. Careful consideration should also be given to the variables chosen. The development of anoxic conditions in at least four of the lakes would favour the use of anaerobes such as denitrifiers, sulphate-reducers and methanogens as indicators of eutrophic conditions, but there is insufficient information on their depth distribution and activity in the sediments of other lakes to determine whether such measurements would be of more general value. 
Analyses of the plankton have shown a steady transition from oligotrophic to eutrophic conditions and therefore further study of this community might provide finer resolution of the state of a particular lake and its position in a series. The results from the benthos, on the other hand, were less reproducible and tended to be discontinuous, possibly placing the lakes in groups rather than on a series. The use of benthic animal populations as indicators of trophic status may be more successful (Brinkhurst, 1974) and microbiological studies might be more profitably applied to the plankton or certain taxonomic or metabolic groups in the benthos.

We are extremely grateful to $\mathrm{K}$. Shepherd for his assistance in the sampling programme and providing the oxygen and temperature data, to all who gave access and permission to sample the lakes, to Dr A. Fishwick of the Lake District Special Planning Board for valuable discussions on the population census and to S. Irwin and D. A. Nicholl for their technical assistance. M.J.L.G.O. was in receipt of a CAPES scholarship.

\section{REFERENCES}

Brinkmurst, R. O. (1974). The Benthos of Lakes. London: Macmillan.

Collins, V. G. \& Willoughby, L. G. (1962). The distribution of bacteria and fungal spores in Blelham Tarn with particular reference to an experimental overturn. Archiv für Mikrobiologie 43, 294-307.

Edmondson, W. T. (1966). Changes in the oxygen deficit of Lake Washington. Verhandlungen der Internationalen Vereinigung für theoretische und angewandte Limnologie 16, 153-158.

George, D. G. \& Heaney, S. I. (1978). Factors influencing the spatial distribution of phytoplankton in a small productive lake. Journal of Ecology 66, 133-155.

GillesPIE, P. A. (1976). Heterotrophic potentials and trophic status of ten New Zealand lakes. New Zealand Journal of Marine and Freshwater Research 10, 91-107.

Gorham, E., Lund, J. W. G., Sanger, J. E. \& DEAN, W. E. (1974). Some relationships between algal standing crop, water chemistry and sediment chemistry in the English Lakes. Limnology and Oceanography 19, 601-617.

Hall, G. H., Collins, V. G., Jones, J. G. \& Horsley, R. W. (1978). The effect of sewage effluent on Grasmere (English Lake District) with particular reference to inorganic nitrogen transformations. Freshwater Biology 8, 165-175.

Harris, R. F. \& Sommers, L. E. (1968). Platedilution frequency technique for assay of microbial ecology. Applied Microbiology 16, 330-334.

HEANEY, S. I. (1976). Temporal and spatial distribution of the dinoflagellate Ceratium hirundinella O.F. Müller within a small productive lake. Freshwater Biology 6, 531-542.

Hutchinson, G. E. (1957). Redox potential and the iron cycle. In A Treatise on Limnology, vol. 1, Geography, Physics, and Chemistry, ch. 2. New York: John Wiley.

JoNes, J. G. (1971). Studies on freshwater bacteria: factors which influence the population and its activity. Journal of Ecology 59, 593-613.

JONES, J. G. (1972). Studies on freshwater microorganisms: phosphatase activity in lakes of differing degrees of eutrophication. Journal of Ecology 60, 777-791.

JoNES, J. G. (1973). Use of non-parametric tests for the analysis of data obtained from preliminary surveys: a review. Journal of Applied Bacteriology 36, 197-210.

JoNES, J. G. (1976). The microbiology and decomposition of seston in open water and experimental enclosures in a productive lake. Journal of Ecology 64, 241-278.

JONES, J. G. (1977). The effect of environmental factors on estimated viable and total populations of planktonic bacteria in lakes and experimental enclosures. Freshwater Biology 7, 6791.

JoNES, J. G. (1979). Microbial activity in lake sediments with particular reference to electrode potential gradients. Journal of General Microbiology 115, 19-26.

JONES, J. G. \& SiMON, B. M. (1975). An investigation of errors in direct counts of aquatic bacteria by epifluorescence microscopy, with reference to a new method for dyeing membrane filters. Journal of Applied Bacteriology 39, 317-329.

JoNes, J. G. \& Simon, B. M. (1977). Increased sensitivity in the measurement of ATP in freshwater samples with a comment on the adverse effect of membrane filtration. Freshwater Biology 7, 253-260.

Jones, J. G. \& Simon, B. M. (1979). The measurement of electron transport system activity in freshwater benthic and planktonic samples. Journal of Applied Bacteriology 46, 305-315.

KITAGAwa, N. (1978). A classification of Japanese lakes based on hypolimnetic oxygen and benthonic fauna. Japanese Journal of Limnology 39, 1-8.

LuND, J. W. G. (1957). Chemical analysis in ecology illustrated from Lake District tarns and lakes. 2. Algal differences. Proceedings of the Linnean Society of London 167, 165-171.

Lund, J. W. G., Kipling, C. \& Le Cren, E. D. (1958). The inverted microscope method of estimating algal numbers and the statistical basis of estimates by counting. Hydrobiologia 11, 143170. 
MACAN, T. T. (1970). Biological Studies of the English Lakes. London: Longmans.

MACKereTH, F. J. H. (1957). Chemical analysis in ecology illustrated from Lake District tarns and lakes. 1. Chemical analysis. Proceedings of the Linnean Society of London 167, 159-164.

MACKERETH, F. J. H. (1964). An improved galvanic cell for determination of oxygen concentrations in fluids. Journal of Scientific Instruments 41, 38-41.

MACKeRETH, F. J. H. (1966). Some chemical observations on post-glacial lake sediments. Philosophical Transactions of the Royal Society of London, Series B 250, 165-213.

Mortimer, C. H. (1942). The exchange of dissolved substances between mud and water in lakes. III and IV. Journal of Ecology 30, 147-201.

Odum, E. P. (1971). Fundamentals of Ecology, 3rd edn. Philadelphia: W. B. Saunders.

OWENS, T. G. \& KING, F. D. (1975). The measurement of respiratory electron-transport system activity in marine zooplankton. Marine Biology 30, 27-36.

Pearsall, W. H. (1921). The development of vegetation in English Lakes considered in relation to the general evolution of glacial lakes and rock basins. Proceedings of the Royal Society of London B92, 259-284.

Pearsall, W. H. (1932). Phytoplankton in the English Lakes. II. The composition of the phytoplankton in relation to dissolved substances. Journal of Ecology 20, 241-258.

Pennington, W. (1974). Seston and sediment formation in five Lake District lakes. Journal of Ecology 62, 215-251.

Pennington, W. (1978). Responses of some British lakes to past changes in land use on their catchments. Verhandlungen der Internationalen Vereini- gung für theoretische und angewandte Limnologie 20, 636-641.

Ramsbotrom, A. E. (1976). Depth charts of the Cumbrian lakes. Freshwater Biological Association Scientific Publication No. 33.

RouND, F. E. (1957). Studies on bottom living algae in some lakes of the English Lake District. 1. Some chemical features of the sediments related to algal productivities. Journal of Ecology 45, 133148.

SCHINDLER, D. W. (1971). A hypothesis to explain differences and similarities among lakes in the experimental lakes area, Northwestern Ontario. Journal of the Fisheries Research Board of Canada 28, 295-301.

Shannon, E. E. \& Brezonik, P. L. (1972). Eutrophication analysis: a multivariate approach. Journal of the Sanitary Engineering Division of the American Society of Civil Engineers 98, 37-57.

SPENCER, M. J. (1978). Microbial activity and biomass relationships in 26 oligotrophic to mesotrophic lakes in South Island, New Zealand. Verhandlungen der Internationalen Vereinigung für theoretische und angewandte Limnologie 20, 1175-1181.

STEWART, K. M. (1976). Oxygen deficits, clarity, and eutrophication in some Madison lakes. Internationale Revue der gesamten Hydrobiologie 61, 563-579.

TAlling, J. F. (1971). The underwater light climate as a controlling factor in the production ecology of freshwater phytoplankton. Mitteilungen der Internationalen Vereinigung für theoretische und angewandte Limnologie 19, 214-243.

WINNER, R. W. (1972). An evaluation of certain indices of eutrophy and maturity in lakes. Hydrobiologia 40, 223-245. 